\title{
Erratum to: Medical devices for pregnancy and childbirth in the developing world
}

\author{
Lucy Thairu $\cdot$ Meg Wirth
}

Published online: 5 September 2012

(C) IUPESM and Springer-Verlag 2012

Erratum to: Health Technol.

DOI 10.1007/s12553-012-0033-4

Unfortunately, the original version of this article contains a mistake. The name of the second author Meg Wirth had inadvertently been omitted.

The online version of the original article can be found at http://dx.doi.org/ 10.1007/s12553-012-0033-4.

L. Thairu $(\bowtie)$

Public Health Program, Touro University,

1310 Club Drive,

Vallejo, CA 94592, USA

e-mail: lucy.thairu@tu.edu

M. Wirth

Maternova, 460 Harris Ave., Suite 201,

Providence, RI 02909, USA

e-mail: mwirth@maternova.net 